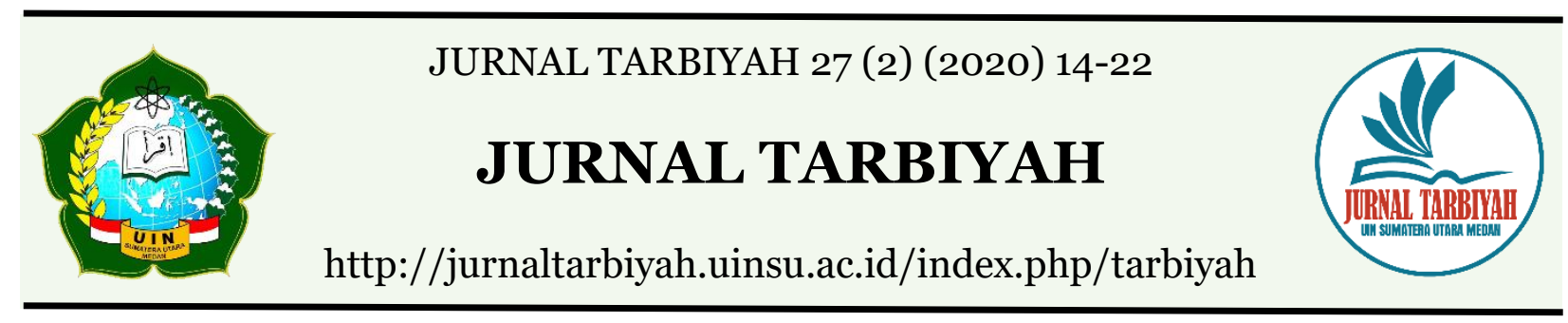

\title{
EXPECTING THE RETURN OF UIN SUMATERA UTARA'S latHIVa IN THE PREVENTION OF HIV AND AIDS IN NORTH SUMATERA
}

\author{
Achmad Ramadhan \\ Universitas Islam Negeri Sumatera Utara, Medan, Indonesia \\ Email : ahmadramadhan@uinsu.ac.id
}

DOI : 10.30829/tar.v27i2.775

Accepted: September 29th, 2020. Approved: December 25th, 2020. Published: December 31th, 2020

\begin{abstract}
As a reflection, when latHIVa was established as a non-structural institution at UIN Sumatera Utara (UiN SU) to tackle HIV and AIDS, the discovery of HIV and AIDS cases at the international level were around 34.3 million people living with HIV, while in 2019 it was estimated that 36.9 million people living with HIV. The cases of HIV and AIDS at the national level in 2000 were 1500 people living with HIV / AIDS (PLWHA) while in 2019 there were 349,882 PLWHA in North Sumatra, and in 2000 there were 30 people living with HIV, while the cases of HIV / AIDS at the level of North Sumatra Province up to August 2019 were 9362 PLWHA. The description of the HIV and AIDS case above describes the epidemic process since the formation of the UIN Sumatera Utara's latHIVa until August 2019. The HIV and AIDS epidemic is like an iceberg phenomenon, which means the numbers of HIV and AIDS cases found above are not the actual numbers. HIV and AIDS do exist. Therefore, WHO (World Health Organization) has formulated that to find out the real numbers, the numbers obtained must be multiplied by 100-200. Thus, if 9362 cases of HIV and AIDS in North Sumatra is multiplied by 100, then there might be 936,200 cases of PLWHA in North Sumatra. Thus, there are around 900 thousand PLWHA who have not been found in North Sumatra.
\end{abstract}

Keywords : latHIVa, UIN Sumatera Utara, HIV, AIDS 


\section{INTRODUCTION}

The relationship between Universitas Islam Negeri Sumatera Utara (UIN SU) and the response to AIDS started from the implementation of the United Nations Development Programs (UNDP) Innovative Pilot Project called as the Center for Information and Counseling HIV / AIDS latHIVa IAIN Sumatera Utara and the signing of a Cooperation Agreement between Komisi Penanggulangan AIDS (KPA) and IAIN Sumatera Utara. The name latHIVa was given by the Rector of IAIN Sumatera Utara, Prof. Dr. H. A. Yakub Matondang. The name was inspired by the meaning of the word lathif (gentle, polite) in Arabic. From this name, it is hoped that LatHIVa can carry out HIV and AIDS prevention efforts wisely and without coercion and violence.

When presenting her paper at the HIV / AIDS Orientation Meeting for IAIN SU and Islamic Organizations Officials, on April 20, 2000 at Campus II UIN Sumatera Utara at Jl. Pancing, dr. Linda Maas, M.P.H stated that the problem of HIV and AIDS involves various aspects of life, including those related to religion. She also mentioned that there is no HIV and AIDS information center that is truly capable of providing accurate and comprehensive information services with a religious background for youth. Thus, UIN Sumatera Utara with its various faculties and community service institutions is considered capable of making a very significant contribution in preventing HIV and AIDS transmission, especially in North Sumatra.

In detail, the benefits of establishing an HIV and AIDS information center at UIN Sumatera Utara, according to dr. Linda Maas, M.P.H are as follows:

1. Accelerating the dissemination of HIV / AIDS information among UIN SU students through the Peer Group Education approach.

2. latHIVa is a place of reference for developing approaches through religious institutions in the response to HIV / AIDS, both youth, student groups and the general public.

3. UIN Sumatera Utara indirectly participates in the socialization of HIV / AIDS prevention in the community

4. UIN Sumatera Utara participates in increasing the socialization of HIV / AIDS response to religious institutions both educational and social, such as Islamic boarding schools, madrasahs, Majelis Ta'lim; Mosque's Youth Community. 


\section{THE DESCRIPTION OF HIV AND AIDS IN NORTH SUMATRA}

As a reflection, when the formation of latHIVa as a non-structural institution at UIN North Sumatra to tackle HIV and AIDS, the discovery of HIV and AIDS cases at the international level was around 34.3 million people living with HIV, while in 2019 it was estimated that there were 36.9 million people living with HIV. There were 1500 people living with HIV and AIDS at the national level in 2000, while in 2019 there were 349,882 people living with HIV and in North Sumatra in 2000 as many as 30 people living with HIV, and HIV / AIDS cases at the level of North Sumatra Province until August 2019 were 9362 PLWHA.

The description of HIV and AIDS cases above describes the epidemic process since the formation of UIN Sumatera Utara's latHIVa until August 2019. The description of the HIV and AIDS epidemic is like an iceberg phenomenon in which the number of HIV and AIDS cases described above are not the actual numbers. HIV and AIDS do exist. Therefore, WHO (World Health Organization) has formulated that to find out the real numbers, the number obtained must be multiplied by 100-200. Thus, there are around 900 thousand people living with HIV / AIDS who have not been found in North Sumatra. The conditions above are a comparison of the number of cases at the international, national and North Sumatra provincial levels in the series of years since the formation of latHIVa until 2019. In connection with the number of cases at the provincial level above, it does not include the number of HIV and AIDS cases originating from the UIN SU's academic community. Indeed, in the year of LATHIVa, HIV and AIDS cases had not been found in the academic community of UIN SU. However, in preventing HIV and AIDS, the author has tried to find alumni and students of UIN Sumatera Utara who are living with HIV and AIDS.

In addition to finding people living with HIV and AIDS, the author also received information about people with HIV and AIDS who had an educational background from UIN Sumatera Utara from the HIV and AIDS care institutions in Medan. These caring institutions usually provide such information to the author because they know the status and background of the author's main day-to-day institution. In addition to the two methods of finding people with HIV and AIDS above, the author also obtained information about people with HIV and AIDS through VCT clinics.

Voluntary Counseling and Testing (VCT) is a clinic established by the Ministry of Health of the Republic of Indonesia at the Hospital. The term has been translated into Indonesian, namely Klinik KTS (Konseling dan Testing Sukarela). This clinic provides 
HIV and AIDS counseling and testing services for people who want to find out their HIV and AIDS status and get counseling. In connection to the number of people with HIV and AIDS who have an educational background in the UIN SU, 6PLWHA were found by using the three methods mentioned above.

\section{THE MODE OF TRANSMISSION OF THE HIV}

Before disclosing the mode of transmission of the HIV, an explanation of what the HIV is and how AIDS emerges will be disclosed first and afterwards how the virus is transferred from one person to another. HIV is an acronym for Human Immunodeficiency Virus, which means a virus that attacks the human immune system and then causes AIDS. From this definition it can be understood that the HIV virus only exists in humans, not in other types of living things such as animals, plants, and it may transfer from one person to another. Thus, some people who concern about transmission of the HIV virus from animals, such as mosquitoes, or other types of animals can be eliminated. He also added that the HIV virus attacks a type of white blood cells that are responsible for warding off infection. These white blood cells include lymphocytes called T-lymphocytes which are known by other medical terms such as T-4 cells and CD-4 cells.

AIDS is an acronym for Acquired Immuno Deficiency Syndrome. Detailed word by word explanation is necessary to understand this. Acquired means obtained. A person who has symptoms of this disease is related to their behavior, not because the person is descended from an ODHA in a family. Immuno means the immune system. Deficiency means deficiency and Syndrome is a collection of symptoms. Thus, AIDS is a disease caused by the HIV virus which destroys the human immune system. Therefore, one's body susceptible to other diseases can be fatal, even though the disease will not cause significant disturbances to people with normal immune systems.

There are several types of viruses in the human body that have certain patterns of transmission that differ from one another. These viruses include Ebola, Dengue, Herpes Simplex, and HIV. HIV will weaken human immunity and transmission, and it can occur in several ways, namely: sexual contact (either heterosexual or homosexual), contact with blood (use of unsterile needles) or infectious secretions, mother to child during pregnancy, childbirth and breastfeeding. This virus will not be transmitted through direct daily contact, such as touching, shaking hands and hugging. If this virus continues to develop, this virus will cause symptoms of various diseases, such as infections in the skin, digestive infections, infections in the lungs and other kinds of infectious diseases. 
In relation to the HIV and AIDS transmission experienced by PLWHA from UIN $\mathrm{SU}$, the author found that sex is one of the triggering factors (the perpetrator had sexual relations with the same sex) and injection-type drug abuse by husbands who contracted HIV from fellow abusers. The injection-type drugs transmit the HIV to his wife. In general, in Indonesia, including the Province of North Sumatra, risk factors for sex and injection-type drug abuse are the main factors that lead to cases of HIV transmission.

From the description above, it is concluded that HIV transmission can occur in the following ways:

1. Sex

2. Injection-type drug abuse

3. Blood contact

4. Mother to child through the process of pregnancy, childbirth and breastfeeding

\section{EFFORTS IN PREVENTING HIV AND AIDS}

When the main team of the Komisi Penanggulangan AIDS dan Narkoba Daerah (KPAND) of North Sumatra Province that is led by the Chief Executive, dr. Linda T. Maas, M.P.H communicated the formation of latHIVa to the Rector of IAIN Sumatera Utara, the UIN Sumatera Utara's academic community did not know and understand the problem of HIV and AIDS, let alone have campus residents who have HIV and AIDS. Nonstructural and structural institutions did not yet have HIV and AIDS prevention programs. At that time, HIV and AIDS was generally understood to be a problem that was raised only by people who engaged in multiple sex activities. This kind of understanding is still very dominant in the community in general so that it has an impact on the lack of participation in taking part in the response to HIV and AIDS because participation in the response to HIV and AIDS is considered to be helping people who have committed adultery.

Furthermore, the development of HIV and AIDS cases from 2000 to 2019 shows a description that contradicts with the initial understanding above. It turns out that the latest facts on HIV and AIDS cases illustrate that the risk factors for HIV and AIDS are very diverse, including the injection of drug abuse, the transmission through needles in health services, the transmission from pregnant women to their baby, and the transmission from blood transfusion. The condition of the development of HIV and AIDS cases above, especially the background of the sufferers, the number of cases and risk 
factors, should encourage all parties to participate in the prevention of HIV and AIDS. Besides that, the wrong perception about this countermeasure should be eliminated.

The prevention of HIV and AIDS in North Sumatra is currently not only carried out by Non-Government Organizations (NGOs) that care about AIDS, but also by institutions or organizations with a religious background, such as Muhammadiyah in North Sumatra which formed TB-HIV Care Aisyiyah to tackling Tuberculosis as well as HIV; Huria Kristen Batak Protestant (HKBP) which formed a special institution to tackle HIV and AIDS called the HKBP AIDS Committee; The Protestant Batak Karo Church (GBKP) which formed the HIV-AIDS \& Drug Services Commission. Thus, there are still very few organizations or institutions with Islamic backgrounds participating in the response to HIV and AIDS in North Sumatra.

The formation of latHIVa at the UIN SU in 2000 is the only Islamic higher education institution that participates in the prevention of HIV and AIDS in North Sumatra, even at the national level. latHIVa is also a representation of Islamic institutions that care about HIV and AIDS. Furthermore, latHIVa carries out various HIV and AIDS prevention programs and activities, such as socialization or orientation of HIV and AIDS issues to campus residents, leaders, staff, lecturers, and students of UIN SU. Outside the campus, latHIVa disseminates information on HIV and AIDS to community religious groups, such as Majelis Ta'lim, Mosque's Youth Community, Islamic community organizations, and Islamic educational institutions, such as madrasas and Islamic boarding schools.

In addition to socialization in the form of meetings, latHIVa also carried out an institutional strengthening program by recruiting volunteers from UIN SU's students from various faculties with a peer education approach; publishing communication, information and education media whose content is related to HIV and AIDS information in a short, simple and precise form, in the form of newsletters, brochures, leaflets, key chains and T-shirts as a means of conveying information, publication and promotion in the management of HIV prevention and AIDS.

Initially, the delivery of information or HIV and AIDS problems by UIN SU's latHIVa volunteers to the Muslim community did not get a good response. It was found that at least this is caused by the lack of intense socialization about the issue of HIV and AIDS to volunteers, or to the status of the informants who do not have a health background, but have a background in Islamic religious education. 
However, with the training obtained by latHIVa volunteers at the time through the Focus Group Discussion (FGD) program which takes place once a week, and also refresher knowledge through training guided by doctors who are specialists in their fields, become latHIVa volunteers at UIN SU. They are motivated to increase their capacity in communicating HIV and AIDS and drug issues, so that the quality of their answers to the questions given in the HIV and AIDS education and outreach program is very satisfying to the attendees.

Indeed, it needs strategies in order to convey information about HIV and AIDS to Muslims because most people have not been well and continuously informed about HIV and AIDS. Some of them still think that HIV transmission is through sexual intercoursefree and alternate (adultery). Consequently, the awareness about HIV and AIDS prevention did not get the response and attention from the Muslim community, especially Islamic leaders, let alone get a portion of the conversation in the discussion of religious issues held by Islamic community organizations.

By looking at this fact, it can be understood that awareness about HIV and AIDS is a problem that not only gets the attention of the concerned agencies at the provincial and national level, but also internationally. The attention of international institutions is not only in the form of providing budgetary assistance, especially for Indonesia, but also in the form of program interventions which sometimes need to be studied and evaluated whether they are compatible with or against Islamic and Eastern values. For this reason, it is hoped that the direct concern and participation of Islamic institutions in the response to HIV and AIDS is realized.

At present, institutions with non-Islamic backgrounds are not only concentrating on preventive programs aimed at low risk groups and not yet infected with HIV, but also at high risk groups and already infected with HIV.

With the provision of skills and knowledge about HIV and AIDS obtained through training carried out by the North Sumatra Provincial KPA and other AIDS Care NGOs, latHIVa volunteers can run their organizations properly and community acceptance is getting better too.

LatHIVa volunteers have used a variety of methods in implementing Islamic, innovative and effective HIV prevention programs, such as the publication of newsletters, leaflets, brochures, telephone counseling, Focus Group Discussions (FGD), discussions, seminars, exhibitions on campus, carnivals, as well as dialogue via radio broadcasts relating not only to HIV and AIDS but also drugs. 


\section{FACTORS CONTRIBUTED TO THE TRANSMISSION OF HIV}

As previously explained, the risk factors for sex (first dominant) and injection drug abuse (second dominant) are the dominant risk factors in the prevention of HIV transmission in North Sumatra Province. This means that community groups classified as high risk are the main contributor to the emergence of HIV and AIDS cases in North Sumatra.

In the discourse on the prevention of HIV and AIDS, the high risk group consists of a population in North Sumatra as illustrated in the following table:

\begin{tabular}{|l|l|l|}
\hline NO. & \multicolumn{1}{|c|}{ POPULATION } & \multicolumn{1}{c|}{ ESTIMATED NUMBER } \\
\hline 1. & MSM (Men Sex with Men) & 45.263 \\
\hline 2. & Indirect CSW & 5.116 \\
\hline 3. & Customers of Indirect CSW & 90.881 \\
\hline 4. & Direct CSW & 9.032 \\
\hline 5. & Customers of direct CSW & 171.981 \\
\hline 6. & Transgenders & 2866 \\
\hline 7. & Transgender customers & 45.044 \\
\hline 8. & Injecting Drug Users & 3.990 \\
\hline
\end{tabular}

The table above provides information about the existence of the High Risk group with an estimated number of them in the community, which is likely the number above is smaller than the actual reality today. This is very reasonable given the oral NGO report delivered by an NGO Caring about AIDS at a Stakeholder Meeting of KPA members in North Sumatra Province at the Melati Room at the Governor's Office of North Sumatra on 30 July 2019 in that they assisted 1000 LGBT people every month in 2019. On that occasion, the LGBT background was also conveyed, some of whom came from UIN SU. This assistance was provided because the LGBT people concerned had problems with HIV and AIDS. In addition, the increase in HIV and AIDS cases in North Sumatra is also quite significant, as conveyed by the Head of the P2PL Division of the North Sumatra Provincial Health Office, dr. N. G. Hikmet, at the Press Release Meeting in commemoration of World AIDS Day in 2019 at the Provincial KPA Secretariat that throughout 2019 101,940 people had been examined and the result was 2087 people infected with HIV.

The table above also provides information that the number of sex buyers is greater than the number of sellers. This condition implies that there must be program 
intervention for customers of CSWs so that they stop committing adultery activities. The problem is "where are the customers?"

If strategic programs are not carried out to direct or eliminate bad behavior from the population of the High Risk group above, HIV and AIDS cases will someday boom in North Sumatra which is even more devastating than the explosion carried out by the terrorists. Na'udzubillah min Dzalik!

\section{CONCLUSION}

The prevention of HIV and AIDS should involve all parties, the government, elements of society, Toga \& Toma, and Public and Religious Universities. Public and Religious Universities can no longer say that the issue of HIV and AIDS is not a problem that should be thought about and is far from the involvement of his academic community. Wallahu A'lam bi Ash-Shawab.

\section{REFERENCES}

Dinas Kesehatan Provinsi Sumatera Utara, Pusyansus RSH. Adam Malik, Global Fund AIDS Provinsi Sumatera Utara, Editor: Umar Zein, 100 Pertanyaan Seputar HIV/AIDS Yang Perlu Anda Ketahui, USU Press, 2006.

Komisi Penanggulangan AIDS (KPA) Nasional, Mengenal dan Menanggulangi HIV/AIDS, Tanpa Tahun Terbit.

Joint United Nations Programme on HIV/AIDS (UNAIDS), Report on the Global HIV/AIDS Epidemic, June 2000

Linda T. Maas, dr. M.P.H., Pengembangan Pusat Informasi dan Konseling HIV/AIDS "Lathifa" di Kampus IAIN-SU, hal. 4 - 5. Makalah disajikan pada Orientasi HIV/AIDS bagi Pejabat IAIN SU dan Ormas Islam Sumut, tanggal 20 April 2000.

Tim Lintas Media, Kamus Arab-. dan Indonesia-Arab, Lintas Media, Jombang, Edisi Terlaris, Tanpa Tahun Terbit. 